\title{
Diagnosis and treatment of bacterial prostatitis
}

\author{
Jerneja Videčnik Zorman ${ }^{1}$, Mojca Matičičč ${ }^{1}$ Samo Jeverica², Tomaž Smrkolj³
}

\begin{abstract}
Prostate inflammation is a common syndrome, especially in men under 50. It usually presents with voiding symptoms and pain in the genitourinary area, and sometimes as sexual dysfunction. Based on clinical and laboratory characteristics, prostatitis is classified as acute bacterial prostatitis, chronic bacterial prostatitis, chronic inflammatory and non-inflammatory prostatitis or chronic pelvic pain syndrome, and asymptomatic inflammatory prostatitis. Bacterial prostatitis is most often caused by infection with uropathogens, mainly Gram-negative bacilli, but Gram-positive and atypical microorganisms have also been identified as causative organisms of chronic prostatitis. According to reports by several authors, Chlamydia trachomatis and Trichomonas vaginalis are some of the most common pathogens, making chronic prostatitis a sexually transmitted disease. Diagnosis and treatment of acute and chronic bacterial prostatitis in particular can be challenging.
\end{abstract}

Keywords: bacterial prostatitis, diagnosis, treatment, sexually transmitted disease

Received: 15 April 2015 | Returned for modification: 3 May 2015 | Accepted: 29 May 2015

\section{Introduction}

Prostate inflammation is an important health issue in sexually active men. It is characterized by high prevalence and frequent recurrences and can have an impact on quality of life because of voiding symptoms, pain, and sexual dysfunction (1). The prevalence of symptoms suggesting prostatitis is approximately $8.2 \%$ (2). They account for $8 \%$ of visits to urologists and up to $1 \%$ of visits to primary care physicians $(2-5)$.

The prostate gland has several natural defense mechanisms against infection: the production of antibacterial substances and mechanical flushing of the prostatic part of the urethra by voiding and ejaculation. Poor drainage of secretions from distal ducts or urine reflux into prostate tissue can lead to inflammation, scaring, or formation of stones. The majority of bacterial prostatitis follows a urinary tract infection $(6,7)$. Risk factors for bacterial prostatitis are stricture of the urethra, urinary tract instrumentation (i.e., transrectal biopsy of the prostate gland), or urethritis due to sexually transmitted pathogens $(8,9)$.

\section{Classification}

Prostatitis is a broad diagnosis that encompasses four clinical entities, from acute febrile illness requiring immediate antimicrobial treatment to an incidental finding in an asymptomatic male noted during an evaluation for other urologic conditions.
Based on clinical and laboratory presentation, prostatitis is classified into the following categories as recommended by the United States National Institutes of Health (Table 1) (10).

\section{Acute bacterial prostatitis}

A small minority of men, less than $1 \%$ of all prostatitis cases, have acute bacterial prostatitis. This is an acute febrile illness, and prompt antibiotic treatment is necessary. The patient presents with symptoms of urinary tract infection (urgency and dysuria), prostate inflammation (perineal, penile, or rectal pain), and systemic infection (fever and malaise). The prostate gland is tender and enlarged on rectal examination. A swollen enlarged prostate may rarely cause obstruction of urine flow. Acute prostatitis can lead to prostatic abscess or epididymitis. A prostatic abscess is suspected when a patient fails to improve despite proper antibiotic treatment. It is estimated that in 5 to $10 \%$ of cases acute inflammation can result in chronic prostatitis (11).

\section{Chronic bacterial prostatitis}

Chronic bacterial prostatitis accounts for 5 to $10 \%$ of all prostatitis cases. Symptoms of prostate inflammation last for more than 3 months. Patients complain of urgency, dysuria, and perineal, penile, or even lower back pain. When urine cultures obtained over the course of an illness repeatedly grow the same bacterial strain,

Table 1 | National Institutes of Health Consensus Classification of Prostatitis (10).

\begin{tabular}{ll}
\hline Type & Description \\
\hline I. Acute bacterial prostatitis & $\begin{array}{l}\text { Acute inflammation of the prostate with PMNL and bacteria in urine } \\
\text { Chronic inflammation of the prostate with PMNL and bacteria in EPS/urine after prostate mas- } \\
\text { II. Chronic bacterial prostatitis }\end{array}$ \\
$\begin{array}{ll}\text { III. Chronic prostatitis/chronic pelvic pain syndrome } \\
\text { - Inflammatory }\end{array}$ & $\begin{array}{l}\text { Symptoms of prostatitis and: } \\
\text { - Noninflammatory }\end{array}$ \\
\hline IV. Asymptomatic prostatitis & PMNL and/or bacteria in EPS/urine after prostate massage or in semen or in the prostate tis- \\
\hline
\end{tabular}

Note. $\mathrm{PMNL}=$ polymorphonuclear leucocytes, EPS = expressed prostatic secretions

${ }^{1}$ Clinic for Infectious Diseases and Febrile Illnesses, University Clinical Centre Ljubljana, Ljubljana, Slovenia. ${ }^{2}$ Institute of Microbiology and Immunology, Faculty of Medicine, University of Ljubljana, Ljubljana, Slovenia. ${ }^{3}$ Department of Urology, University Clinical Centre Ljubljana, Ljubljana, Slovenia. $\bowtie$ Corresponding author: jerneja.videcnik@gmail.com 
chronical bacterial prostatitis can be suspected with high certainty. However this finding is present in less than half of patients (12). Between symptomatic episodes, the patient may be completely symptom-free. In patients with recurrent urinary tract infection, detailed examination must be performed to exclude any anatomical abnormalities predisposing to infection (i.e., stones or foreign bodies within the urinary tract, bladder cancer, enterovesical fistula, etc.).

\section{Chronic prostatitis or chronic pelvic pain syndrome}

Chronic prostatitis or chronic pelvic pain syndrome (inflammatory and noninflammatory) represents the vast majority (80 to 90\%) of all prostatitis cases. Patients experience pelvic or perineal pain and possible voiding symptoms. Based on the presence of white blood cells present in expressed prostate secretions, semen, or urine after prostate massage, chronic prostatitis is subdivided into two categories: inflammatory and noninflammatory.

\section{Asymptomatic prostatitis}

Asymptomatic prostatitis accounts for approximately $10 \%$ of all prostatitis cases. It is diagnosed when inflammatory cells are identified on prostate biopsy or noted in semen during urological evaluation for other reasons in a male with no symptoms of prostate inflammation.

\section{Causative organisms in prostatitis}

The most common pathogens of acute and chronic bacterial prostatitis are Enterobacteriae (Escherichia coli, Klebsiella spp., Proteus spp., Pseudomonas spp.). Other microorganisms, such as Enterococcus spp. and Staphylococcus spp., are found less frequently.

Apart from aerobic bacteria, chronic bacterial prostatitis can be due to anaerobes, with Peptostreptococcus spp. and Bacteroides spp. being most often isolated. Because anaerobes are not cultured as part of the routine procedure, their role in bacterial prostatitis may be underestimated $(13,14)$. Samples of urine, expressed prostatic secretions, or semen need to be transported and cultivated under special conditions when anaerobes are suspected.

A significant number of chronic bacterial prostatitis cases are caused by sexually transmitted microorganisms. A study performed by Škerk et al. that included 1,442 males with chronic prostatitis revealed that Chlamydia trachomatis, Trichomonas vaginalis, and Ureaplasma urealyticum were the causative pathogens in half of the patients (15).

The prevalence of urogenital infections with $C$. trachomatis is very similar in both men and women (16). C. trachomatis is transmitted almost exclusively by sexual intercourse, and thus sexually active men under age 35 are usually affected. In men, chlamydial infection can cause urethritis, epididymitis, and chronic prostatitis, and it may also play a role in male infertility (17-20). It has

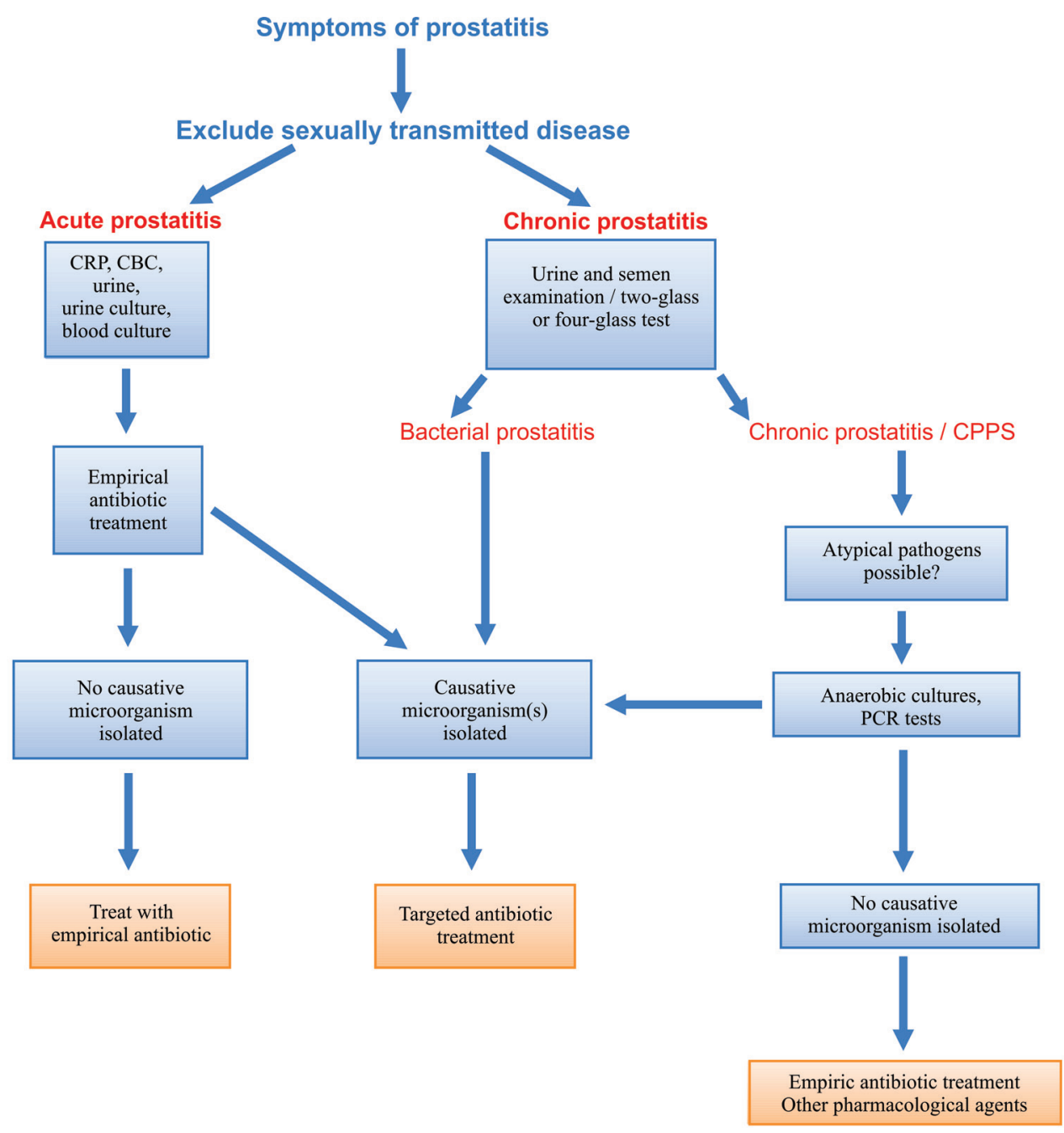

Figure 1 | Diagnosis algorithm for suspected prostatitis. CRP: C-reactive protein, CBC: complete blood count, CPPS: chronic pelvic pain syndome 
been shown in mouse models that $C$. trachomatis may persist in the prostate, establishing an immune-privileged niche, avoiding the host immune system. A chronically infected gland can serve as a reservoir of continuous transmission of infection (21).

Prostatitis caused by Trichomonas vaginalis is more often found in young sexually active men with frequent episodes of urethritis $(15,21)$. Identifying the causative organism is very difficult, with molecular assays being most useful. Neisseria gonorrhoeae is also considered a causative microorganism of prostatitis (15).

\section{Diagnostic tests in suspected prostatitis}

Clinical presentation and laboratory tests are used to differentiate and categorize the four types of prostatitis.

When acute bacterial prostatitis is suspected, midstream urine is examined for bacterial culture, and blood cultures and blood are examined for complete blood count, C-reactive protein, procaltitonin, and prostate-specific antigen (PSA). Prostate massage should not be performed and could be harmful.

In the diagnosis of chronic prostatitis or chronic pelvic pain syndrome, several special diagnostic tests should be performed.

\section{Meares-Stamey four-glass test}

\section{Preparation:}

No antibiotics should have been taken for 1 month before the test, the patient should not have ejaculated for 2 days, and a full bladder is required.

Prostate massage:

- The penis should be cleaned well to prevent contamination.

- A 5 to $10 \mathrm{ml}$ sample of first-void urethral urine is collected (from the distal urethra).

- The patient passes a further 100 to $200 \mathrm{ml}$ of urine and then collects 5 to $10 \mathrm{ml}$ of mid-stream bladder urine.

- By digital rectal examination, massage of the prostate gland is performed for 1 minute and any expressed prostatic secretions (EPS) are collected in a sterile container (a dry prostate massage is reasonably common).

- Immediately after the massage, 5 to $10 \mathrm{ml}$ of post-massage urine is collected.

All three urine samples are examined with microscopy and quantitative culture.

When atypical pathogens are suspected, special microbiological testing should be considered. Prostatitis caused by $C$. trachomatis, $U$. urealyticum, or T. vaginalis can be diagnosed using molecular assays or with isolation of the causative organism in the samples of EPS, semen, or urine after prostate massage with the absence of the organisms in the urethral swab before ejaculation or prostate massage.

For prostate inflammation, $\geq 10$ polymorphonuclear leucocytes (PMNL) per high-power field (400x) is considered diagnostic. In cases of a dry expressate, a PMNL count of 10 per high-power field greater in the last urine sample than in the first and second urine samples is diagnostic. To assign an organism to the prostate, the colony count in the expressed prostatic secretions and in the last urine sample should be at least 10 times greater than in the first and second urine sample (23).

\section{Two-glass test}

The four-glass test is seldom used in regular clinical practice be- cause it is difficult to perform, time-consuming, and unpleasant for the patient. The sensitivity of the two-glass test is similar to the Meares-Stamey four-glass test. Urine samples are obtained before and after prostate massage.

\section{Urine and semen examination}

A first-void urine sample and semen are examined with microscopy and quantitative culture. Budía et al. showed that the sensitivity of semen samples was higher than EPS samples for the diagnosing chronic bacterial prostatitis. For Gram-negative organisms, the sensitivity of semen cultures was $97 \%$ versus to $82.4 \%$ for EPS cultures, and for Gram-positive organisms the sensitivity of semen samples was $100 \%$ versus $16.1 \%$ for EPS (25).

\section{Additional tests}

When a sexually transmitted disease is suspected (especially in men with prostatitis under age 35, older men with multiple sexual partners, etc.), screening for other sexually transmitted infections should be performed: C. trachomatis, Treponema pallidum, $N$. gonorrhoeae, hepatitis B virus, and HIV virus.

Only $60 \%$ of patients with acute prostatitis and $20 \%$ of patients with chronic prostatitis have elevated PSA level. A decrease after successful antibiotic treatment correlates with clinical and microbiological improvement (26-28).

Prostate biopsy culture is neither sensitive nor specific (because inflammation in the gland is not uniformly distributed) (29). When a prostatic abscess is suspected, transrectal ultrasound or a computer tomography scan of the gland should be performed.

\section{Treatment}

Only selected antibiotic compounds are suitable for treating bacterial infection of the prostate. Most antibiotic agents penetrate the acutely inflamed prostate, but this is not the case with a chronically inflamed gland. Prostate capillaries are nonporous and lack an antibiotic transport mechanism. Only non-proteinbound antibiotic molecules with a small molecular size, high lipid solubility, low degree of ionization, and high concentration in the serum can reach an adequate concentration in prostate tissue.

Fluoroquinolones have the best pharmacological properties for treating bacterial prostatitis, allowing concentrations in the prostate to be 10 to $50 \%$ of that in the serum (30-32). Antibiotics with good penetration into the prostate tissue also include trimethoprim-sulfamethoxazole, clindamycin, doxycycline, and azithromycin. Cephalosporins, carbapenems, piperacillin and some of the aminoglycosides also attain therapeutic levels in prostate tissue. Nitrofurantoin levels in the prostate are nontherapeutic (33-39). The major threat is the growing resistance of microorganisms, especially to fluoroquinolones.

There are several differences in treatment recommendations for acute and chronic bacterial prostatitis (40-48). In the case of acute bacterial prostatitis, empirical antibiotic treatment should be started immediately after urine and possible blood cultures are obtained and tailored to the isolated organisms later on. Treatment of chronic bacterial prostatitis should be delayed until culture and susceptibility results are available. When infection with $N$. gonorrhoeae is diagnosed, a patient also has to be treated for possible infection with $C$. trachomatis or urogenital mycoplasma. When a sexually transmitted organism is diagnosed, sexual part- 
ners have to be examined and treated simultaneously. Our recommendations for the treatment of bacterial prostatitis are summarized in Table 2.

When acute urinary retention develops as a complication of acute bacterial prostatitis, suprapubic tap should be performed to alleviate retention because urethral catheterization may worsen infection and is contraindicated.

Prostatic abscesses larger than $1 \mathrm{~cm}$ in diameter should be surgically drained.

Treatment of noninflammatory chronic prostatitis / chronic pelvic pain syndrome is difficult in most cases. In a well-designed systematic study performed by Nickel et al., only one-third of patients had modest improvement during 1 year of follow-up (49). Antimicrobial treatment proved unsuccessful in most cases. Adding an alpha blocker improved symptomatic outcomes, but mainly in patients that were alpha blocker-naive (50). None of the controlled trials support various non-pharmacological methods or surgical procedures (51).

\section{References}

1. McNaughton Collins M, Pontari MA, O'Leary MA, Calhoun EA, Santanna J, Landis $J R$, et al. Quality of life is impaired in men with chronic prostatitis: the chronic prostatitis collaborative research network. J Gen Intern Med. 2001;16:656-62.

2. Krieger JN, Lee SW, Jeon J, Cheah PY, Liong ML, Riley DE. Epidemiology of prostatitis. Int J Antimicrob Agents. 2008;31:S85-90.

3. Mehik A, Hellstrom P, Lukkarinen O, Sarpola A, Jarvelin M. Epidemiology of prostatitis in Finish men: a population-based cross-sectional study. BJU Int. 2000;86:443-8.

4. Rizzo M, Marchettti F, Travaglini F, Trinchieri A, Nickel JC. Prevalence, diagnosis and treatment of prostatitis in Italy: a prospective urology outpatient practice study. BJU Int. 2003;92:955-9.

5. Collins MM, Stafford RS, O'Leary MA, Barry MJ. How common is prostatitis? A national survey of physician visits. J Urol. 1998;159:1224-8.

6. Fair WR, Parrish RF. Antibacterial substances in prostatic fluid. Prog Clin Biol Res. 1981;75:247-64.

7. Nickel JC, Olson ME, Barbas A, Benediktsson H, Dasgupta MK, Costerton JW. Pathogenesis of bacterial prostatitis in an animal model. Br J Urol. 1990;66:47-54.

8. Millan-Rodriguez F, Palou J, Bujons-Tur A, Musquera-Felip M, Sevilla-Cecilia C, Serrallach-Orejas M, et al. Acute bacterial prostatitis: two different sub-categories according to a previous manipulation of the lower urinary tract. World J Urol. 2006;24:45-50.

9. Pontari MA1, Joyce GF, Wise M, McNaughton-Collins M. Urologic Diseases in America project. Prostatitis. J Urol. 2007;177:2050-7.

10. Krieger JN, Nyberg L Jr, Nickel JC. NIH consensus definition and classification of prostatitis. JAMA. 1999;281:236-7.

11. Yoon BI, Han DS, Ha US, Lee SJ, Sohn DW, Kim HW, et al. Clinical courses following acute bacterial prostatitis. Prostate Int. 2013;1:89-93.

12. Nickel JC, Moon T. Chronic bacterial prostatitis: an evolving clinical enigma. Urology. 2005;66:2-8.

13. Magri V, Restelli A, Marras E, Perletti G. A severely symptomatic case of anaerobic chronic bacterial prostatitis successfully resolved with moxifloxacin therapy. Anaerobe. 2010;16:206-9.

14. Szöke L, Török L, Dósa E, Nagy E, Scultéty S. The possible role of anaerobic bacteria in chronic prostatitis. Int J Androl. 1998;21:163-8.

15. Skerk V, Krhen I, Schonwald S, Cajic V, Markovinovic L, Roglic S, et al. The role of unusual pathogens in prostatitis syndrome. Int I Antimicrob Agents. 2004;24:S53-6.

16. Mackern-Oberti JP, Motrich RD, Breser ML, Sánchez LR, Cuffini C, Rivero VE. Chlamydia trachomatis infection of the male genital tract: an update. J Reprod Immunol. 2013;100:37-53.

17. Skerk V, Krhen I, Cajić V, Markovinović L, Puntarić A, Roglić S, et al. The role of Chlamydia trachomatis in prostatitis syndrome-our experience in diagnosis and treatment. Acta Dermatovenerol Croat. 2007;15:135-40.

18. Weidner W, Diemer T, Huwe P, Rainer H, Ludwig M. The role of Chlamydia trachomatis in prostatitis. Int J Antimicrob Agents. 2002;19:466-70.

19. Ouzounova-Raykova V, Ouzounova I, Mitov IG. May Chlamydia trachomatis be an aetiological agent of chronic prostatic infection? Andrologia. 2010;42:176-81.

20. Mazzoli S, Cai T, Addonisio P, Bechi A, Mondaini N, Bartoletti R. Chlamydia trachomatis infection is related to poor semen quality in young prostatitis patients. Eur Urol. 2010;57:708-14.
Table 2 | Recommendations for treatment of acute and chronic prostatitis (40-45).

ACUTE PROSTATITIS: treatment duration 2 to 4 weeks

- Ciprofloxacin $400 \mathrm{mg}$ every $12 \mathrm{~h}$ iv or $500 \mathrm{mg}$ po BID

- Levofloxacin $500 \mathrm{mg}$ every $24 \mathrm{~h}$ iv or $500 \mathrm{mg}$ po QD

- TMP/SMX 160/800 mg po BID

- Gentamicin $5 \mathrm{mg} / \mathrm{kg}$ every $24 \mathrm{~h}$ iv \pm ampicillin $2 \mathrm{~g}$ every $6 \mathrm{~h}$ iv

CHRONIC PROSTATITIS: treatment duration 6 weeks to 3 months

- Ciprofloxacin 500 mg po BID

- Levofloxacin $500 \mathrm{mg}$ po QD

- TMP/SMX 160/800 mg po BID

Pathogen targeted:

- Enterococcus spp.: ampicillin/vankomycin/levofloxacin

- Pseudomonas aeruginosa: ciprofloxacin/piperacillin-tazobactam/ imipenem

- ESBL pos. enterobacteria: ertapenem

- Neisseria gonorrhoeae: ceftriaxone (+ azithromycin/doxycycline)

- Chlamydia trachomatis, urogenital mycoplasma: azithromycin/ doxycycline

- Anaerobes: clindamycin/azithromycin

- Trichomonas vaginalis: metronidazole

21. Mackern Oberti JP, Motrich RD, Breser ML, Cejas H, Cuffini C, Maccioni M, et al. Male rodent genital tract infection with Chlamydia muridarum: persistence in the prostate gland that triggers self-immune reactions in genetically susceptible hosts. J Urol. 2011;186:1100-6.

22. Abdolrasouli A, Amin A, Baharsefat M, Roushan A, Mofidi S. Persistent urethritis and prostatitis due to Trichomonas vaginalis: a case report. Can J Infect Dis Med Microbiol. 2007;18:308-10.

23. Meares EM Jr, Stamey TA. Bacterial localisation patterns in bacterial prostatitis and urethritis. Invest Urol. 1968;5:492-518.

24. Nickel JC, Shoskes D, Wang Y, Alexander RB, Fowler JE Jr, Zeitlin S, et al. How does the pre-massage and post-massage 2-glass test compare to the MearesStamey 4-glass test in men with chromic prostatitis/chronic pelvic pain syndrome? J Urol. 2006;176:119-24.

25. Budía A, Luis Palmero J, Broseta E, Tejadillos S, Benedicto A, Queipo JA, et al. Value of semen culture in the diagnosis of chronic bacterial prostatitis: a simplified method. Scand J Urol Nephrol. 2006;40:326-31.

26. Schaeffer AJ, Wu SC, Tennenberg AM, Kahn JB. Treatment of chronic bacterial prostatitis with levofloxacin and ciprofloxacin lowers serum prostate specific antigen. J Urol. 2005;174:161-4.

27. Sutcliffe S, Nevin RL, Pakpahan R, Elliott DJ, Cole SR, De Marzo AM, et al. Prostate involvement during sexually transmitted infections as measured by prostate-specific antigen concentration. Br J Cancer. 2001;105:602-5.

28. Bozeman CB, Carver BS, Eastham JA, Venable DD. Treatment of chronic prostatitis lowers serum prostate specific antigen. J Urol. 2002;167:1723-6.

29. Lee JC, Muller CH, Rothman I, Agnew KJ, Eschenbach D, Ciol MA, et al. Prostate biopsy culture findings of men with chronic pelvic pain syndrome do not differ from those of healthy controls. J Urol. 2003;169:584-7.

30. Charalabopoulos K, Karachalios G, Baltogiannis D, Charalabopoulos A, Giannakopoulos X, Sofikitis N. Penetration of antimicrobial agents into the prostate. Chemotherapy. 2003;49:269-79.

31. Drusano GL, Preston SL, Van Guilder M, North D, Gombert M, et al. A population pharmacokinetic analysis of the penetration of the prostate by levofloxacin. Antimicrob Agents Chemother. 2000;44:2046-51.

32. Wagenlehner FM, Kees F, Weidner W, Wagenlehner C, Naber KG. Concentrations of moxifloxacin in plasma and urine, and penetration into prostatic fluid and ejaculate, following single oral administration of $400 \mathrm{mg}$ to healthy volunteers. Int J Antimicrob Agents. 2008;31:21-6.

33. Bergmann M, Lederer B, Takacs F. Tissue concentrations of sulfametrol-trimethoprim in the human prostate. Urologe A. 1979;18:335-7.

34. Perletti G, Skerk V, Magri V, Markotic A, Mazzoli S, Parnham MJ, et al. Macrolides for the treatment of chronic bacterial prostatitis: an effective application of their unique pharmacokinetic and pharmacodynamic profile (Review). Mol Med Rep. 2011;4:1035-44.

35. Klotz T, Braun M, Bin Saleh A, Orlovski M, Engeletmann U. Penetration of a single infusion of ampicillin and sulbactam into prostatic tissue during transurethral prostatectomy. Int Urol Nephrol. 1999;31:203-9.

36. Goto T, Makinose S, Ohi Y, Yamauchi D, Kayajima T, Kayajima T, et al. Diffusion of piperacillin, cefotiam, minocycline, amikacin and ofloxacin into the prostate. Int J Urol. 1998;5:243-6. 
37. Nowick WJ Jr. Levels of cefotaxime in body fluids and tissues: a review. Rev Infect Dis. 1982;4:S346-53.

38. Morita M, Nakagawa T, Suzuki K. Ceftazidime concentration in human prostatic tissue and serum following intravenous injection. Hinyokika Kiyo. 1991;37659-62.

39. Nishikawa G, Ikawa K, Nakamura K, Yamada Y, Zennami K. Prostatic penetration of meropenem in humans, and dosage considerations for prostatitis based on a site-specific pharmacokinetic/pharmacodynamic evaluation. Int J Antimicrob Agents. 2013;41:267-71.

40. Lipsky BA, Byren I, Hoey CT. Treatment of bacterial prostatitis. Clin Infect Dis. 2010;50:1641-52.

41. Grabe M, Bartoletti R, Bjerklund-Johansen HM, Cek RS, Pickard P, et al. Guidelines on urological infections. [Internet]. European association of urology. C2015 - [cited 2015 April 13]. Available from: http://www.uroweb.org/guidelines/online-guidelines/?no_cache $=1$.

42. Sharp VJ, Takacs EB. Prostatitis: diagnosis and treatment. A Fam Physician. 2010;82:397-406.

43. British association for the management of sexual health and HIV. United King dom national guideline for the management of prostatitis 2008. [Internet]. C2015 - [cited 2015 April 13]. Available from: www.bashh.org/guidelines.

44. Čižman M, Beović B. Kako predpisujemo protimikrobna zdravila v bolnišnici. Druga dopolnjena izdaja. [Prescribing antimicrobials in a hospital. 2nd ed]. Ljubljana (Slovenia): Sekcija za protimikrobno zdravljenje Slovenskega zdravniškega društva; c2013. p. 87-8. Slovene.
45. Perletti G, Marras E, Wagenlehner FME, Magri V. Antimicrobial therapy for chronic bacterial prostatitis. Cochrane Database Syst Rev. 2013;12:8.

46. Rees J, Abrahams M, Doble A, Cooper A. The Prostatitis Expert Reference Group (PERG). Diagnosis and treatment of chronic bacterial prostatitis and chronic prostatitis / chronic pelvic pain syndrome: a consensus guideline. BJU Int 2015; doi: 10.1111/bju.13101. [Epub ahead of print].

47. Vahlensieck W, Ludwig M, Wagenlehner FM, Naber K, Fabry W. Prostatitis: Diagnostik und Therapie. Aktuelle Urol. 2013;44:117-23. German.

48. Dickson G. Prostatitis-diagnosis and treatment. Aust Fam Physician. 2013; 42:216-9.

49. Nickel JC, Downey J, Ardern D, Clark J, Nickel K. Failure of a monotherapy strategy for difficult chronic prostatitis / chronic pelvic pain syndrome. J Urol. 2004; 172:551-4.

50. Murphy AB, Macejko A, Taylor A, Nadler RB. Chronic prostatitis: management strategies. Drugs. 2009;69:71-84.

51. El-Hakim A, Shah DK, Smith AD. Advanced therapy for prostatitis: minimally in vasive and invasive therapies. Curr Urol Rep. 2003;1:44-50. 